\title{
PSYCHE
}

\begin{tabular}{lll}
\hline VOL. XXXIX & MARCH-JUNE, 1932 & Nos. 1-2 \\
\hline
\end{tabular}

\section{J. H. EMERTON}

\section{BY NATHAN BANKS}

James Henry Emerton was born at Salem, Massachusetts, March 31, 1847, where, as a boy, he attended the local school. He was rather frail and a young helper in his father's drug store, George F. Markoe, interested the boy in outdoor life. They collected plants, insects and shore invertebrates and at the age of fifteen he was frequently visiting the Essex Institute, where he became acquainted with A. S. Packard, F. W. Putnam, John Robinson, Caleb Cooke, and others who later became more or less prominent students of Natural History.

From the first he showed much skill in drawing and made sketches of a great variety of natural objects. He took no lessons in the art, and his later skill in this as well as in modeling was of his own initiative.

In 1868 in the American Naturalist advertiser there appeared the following:- "James H. Emerton, Zoölogical and Botanical Draughtsman, Salem, Mass., is prepared to execute drawings on paper or wood for Zoölogical Subjects. Especial attention given to the delineation of Insects. References: Editors of American Naturalist."

Of these early drawings there are many in Packard's "Guide" and forty quarto plates in Watson and Eaton "Botany of the Fortieth Parallel" published in 1871. He was elected to the Boston Society of Natural History in 
1870, and later, 1873-1874 was an assistant in the Museum. While here he prepared the notes to Hentz's spiders of the United States and the article on cave spiders of Indiana and Kentucky (1875).

He had already decided to study spiders, had collected in over 100 localities in the New England states, and had amassed a collection of more than 300 species.

Early in 1875 he left the Boston Society to spend more than a year in Europe. While there he was enrolled as a student for a short time at the University of Leipzig (October, 1875 to April, 1876) and later (May to July, 1876) at the University of Jena, but apparently he spent much time collecting spiders and becoming acquainted with the arachnologists of Europe, particularly Cambridge, Simon, Koch, Thorell and Ohlert. He had taken to Europe his collection of New England spiders and from Leipzig in December, 1875, wrote an article comparing them with those of the European fauna.

Returning, he again engaged in drawing and prepared many of the colored plates in Eaton's "Ferns of North America" and also many in Packard's "Monograph of the Geometridæ."

In 1877, he gave eight lectures on zoölogy and six on spiders at the Summer School of Biology in Salem, and in 1878 delivered another series of six lectures on spiders. He became a curator in the Museum of the Peabody Academy of Science where he spent an hour each day with the visitors and prepared a Guide to the Museum. In 1879 he also gave instruction in the zoölogical laboratory at Salem.

He spent some time at Albany, N. Y., making drawings for Prof. A. Hall, and later (about 1880) went to New Haven, where he was appointed assistant to Professor A. E. Verrill. He made a host of drawings for Verrill, and prepared the famous models of the great squid and octopus now in the Museum of Comparative Zoölogy at Cambridge and in the National Museum at Washington. For these models he was awarded a medal with an elaborately engraved certificate at the International Fisheries Congress 
in London in 1882. At New Haven in 1884 he married Mary A. Hills, and shortly thereafter moved to Boston, which was henceforth his home. His wife died in 1898.

He did much modeling for medical colleges and made drawings for many persons; as Minot's Textbook of Embryology, Verrill's Marine Invertebrates, Scudder's Butterflies of New England, Peckham's papers on spiders, and many for the U. S. Fish Commission. He was active in various natural history organizations and became an important factor in furthering interest in local science.
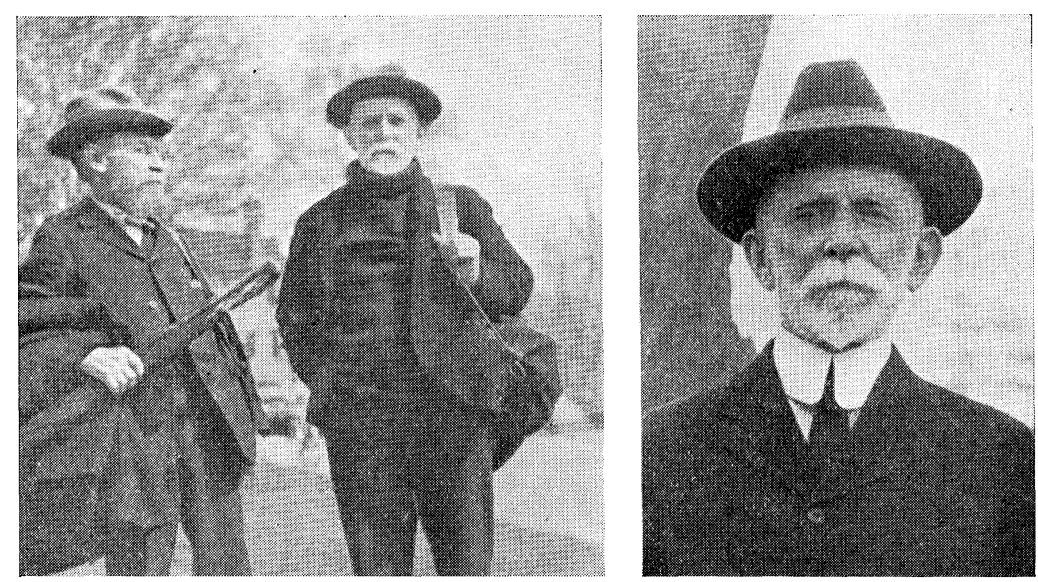

Left. J. H. Emerton and F. Blanchard (about 1905). Right. J. H. Emerton, from a later photograph.

He began to travel more widely, visiting the West Indies in 1893 with Alexander Agassiz, going with Morse in 1902 to the Southern States, in 1905 to the Californian Mountains, in 1914 to the Canadian Rockies, in 1920 to the Hudson Bay Region. On these and numerous shorter trips he industriously collected spiders.

He became much interested in a Federation of New England Natural History Societies, and this he considered as the most useful way of stimulating interest in Natural 
History. He was the Secretary and principal support of this society until his death.

$\mathrm{He}$ was a founder of our Society, for many years an officer, and one of our most regular attendants, often speaking and exhibiting specimens. Some years ago under the auspices of the Club he arranged for two series of public lectures on entomology, giving one lecture himself. $\mathrm{He}$ always seemed to be in good health, and collected spiders only a few months before his death, December 5, 1931.

Aside from being a naturalist he was an artist for the sake of art. He painted hundreds of water colors, often depicting the sea, the shore, or ships. For several seasons this was done at Ipswich, and in later years he went regularly in July to Gloucester for painting. He frequently exhibited before art societies, and lived for many years in an artist's studio apartment.

His principal interest and work was on the taxonomy and distribution of the spiders of New England and Canada. His method of sifting leaves, moss and detritus brought to light great numbers of the smaller forms. At first he sent these to the Rev. O. P. Cambridge in England, who described them; later he began his famous series of New England Spiders, publishing the Theridiidæ in 1882. The plates in these papers were especially valuable; those in the second part (Epeiridæ) containing some of his finest drawings. It is these illustrations that give the characteristic appearance of the parts which have given to $\mathrm{Mr}$. Emerton much of his importance as an arachnologist. Cambridge, in reviewing Hentz's Spiders of the United States (Nature, 1876) refers to Emerton's two plates as follows:- "In point of accurate detail and artistic finish these figures are immeasurably in advance of those engraved from Hentz's drawings."

The series on New England spiders was followed by four supplements, two papers on Canadian spiders and numerous smaller articles, describing in all over 350 species, always with useful illustrations. No other writer has so thoroughly figured his species, old as well as new.

In several papers he traced the distribution of certain 
northern spiders. Several of his early articles dealt with the habits of spiders and, even to the last, he loved to watch each autumn for the flying spiders.

He gave to the Museum of Comparative Zoölogy the first set of the types of his descriptions, his private collection and library he willed to the writer.

His bibliography is as follows:-

The habits of spiders. American Nat., II, 476-481, 1868. The Ant-lion. American Nat. IV, 1871.

Notes on spiders from caves in Kentucky, Virginia and Indiana. American Nat., IX, 278-281, 1875.

(Notes and two plates) Hentz Spiders of the United States. Occ. Pap. Boston Soc. Nat. Hist., II, 1875.

Simon's Les Arachnides de France, Tome I, 1874. American Nat., IX, 108-109, 1875.

Spiders common to New England and Europe. Psyche, I, 129-131, 1876.

A comparison of the spiders of Europe and North America.

Proc. Boston Soc. Nat. Hist., XIX, 68-72, 1877.

Descriptions of two new spiders from Colorado. Bull.

U. S. Geol. Geog. Surv. Terr., III, 528-529, 1877.

Cocoon making and egg-laying of spiders. Psyche, II, 33-34, 1877.

Oviposition in spiders. Psyche, II, 123-124, 1877.

The structure and habits of spiders. 180 pp., S. E. Cassino, Salem, 1878.

Life on the seashore, or animals of our coast and bays.

143 pp. Naturalist Handy Series, Salem, 1880.

Breeding habits of spiders. American Nat., XIV, 595, 1880.

(Mating of Xysticus). American Nat., XIV, 595, 1880. Spider webs. Bull. Essex Institute, IX, 67, 1881.

New England spiders of the family Theridiidæ. Trans. Connecticut Acad. Sci., VI, 1-86, 1882.

The cobwebs of Uloborus. American Journ. Sci., (3) XXV, 203-205, 1883.

New England spiders of the family Epeiridæ. Trans. Connecticut Acad., VI, 295-342, 1884. 
New England spiders of the family Lycosidæ. Trans. Connecticut Acad. Sci., VI, 481-505, 1885.

New England spiders of the family Ciniflonidæ. Trans. Connecticut Acad. Sci., VII, 443-458, 1888.

Habit of Vespa. Psyche, V, 54, 1888.

Habits of Mygale in confinement. Psyche, V, 54, 1888.

Walckenaer's names of American spiders. Psyche, V, $113-114,1888$.

Pairing of Xysticus triguttatus. Psyche, V, 169, 1889.

New England spiders of the families Drassidae, Agelenidæ and Dysderidæ. Trans. Connecticut Acad. Sci., VIII, 166-206, 1890.

New England spiders of the family Attidae. Trans. Connecticut Acad. Sci., VIII, 220-252, 1891.

New England spiders of the family Thomisidæ. Trans. Connecticut Acad. Sci., VIII, 359-381, 1892.

Canadian spiders. Trans. Connecticut Acad. Sci., IX, 400429, 1894.

Common spiders of the United States. 243 pp., Ginn and Company, 1902.

Cocoons and young of Coniopteryx. Psyche, XIII, 74-75, 1906.

A female spider with one male palpus. Psyche, XIV, 40, 1907.

Supplement to New England spiders. Trans. Connecticut Acad. Sci., XIV, 171-236, 1909.

New spiders from New England. Trans. Connecticut Acad. Sci., XVI, 383-407, 1911.

Four burrowing Lycosa (Geolycosa Montg. Scaptocosa Banks) including one new species. Psyche, XIX, 2536, 1912.

(Comstock's Spider Book). Review. Ent. News, 1913, 35-37.

New and rare spiders from within fifty miles of New York City. Bull. American Mus. Nat. Hist., XXXII, 255$260,1913$.

The spiders of three mile island. Appalachia, XII, 154-156, 1913. 
New England spiders identified since 1910. Trans, Connecticut Acad. Aci., XVIII, 209-224, 1913.

New spiders from the neighborhood of Ithaca, N. Y. Journ. New York Ent. Soc., 1914, 262-264.

Geographical distribution of spiders in New England. Appalachia, XIII, 143-159, 1914.

Recent collections of spiders from Newfoundland and Labrador. Ent. News, 1914, 117-118.

New spiders from New England XI. Trans. Connecticut Acad. Sci., XX, 133-144, 1915.

Canadian spiders II. Trans. Connecticut Acad. Sci., XX, 145-160, 1915.

New spiders from Canada and adjoining states. Canadian Entom., 1917, 261-272; No. 2, ibid, 1919, 105-108;

No. 3, ibid, 1923, 238-243; No. 4, ibid, 1925, 65-69;

No. 5, ibid, 1926, 115-119.

Recent studies in Canadian spiders. Canadian Entom., 1917, 13-16.

Spiders in the Adirondacks. Ent. News, 1917, 59-60.

Studies on Canadian Spiders in summer of 1917. Canadian Entom., 1918, 128-129.

A new house spider. Ent. News, 1918, 74.

Transcanadian spiders. Rept. Ent. Soc. Ontario, 1918.

Notes on the spiders collected by Frits Johansen of the

Denmark Expedition 1906-08 to Northeastern Greenland, Latitude $76 \frac{1}{2}$ to 77 North. Vidensk. Medd. Dansk Naturf. Fören., LXX, 143-145, 1918.

The flights of spiders in the Autumn of 1918. Ent. News, 1919, 165-168.

Spiders. Rept. Canad. Arctic Exped., 1913-18, III, part H., p. $3 \mathrm{H}$ to $6 \mathrm{H}$. 1919.

Catalogue of the spiders of Canada known to the year 1919. Trans. Royal Canadian Inst. 1919, 309-338.

Notes on Canadian and Arctic spiders. Psyche, XXVIII, 165-168, 1921.

Recent collections of Canadian spiders. Canadian Entom. 1924, 122-124.

Early history of the Cambridge Entomological Club. Psyche, XXXI, 1-6, 1924. 
New spiders from southern New England. Psyche, XXXI, 140-145, 1924.

New Californian spiders. Pan Pacific Entom, I, 29-31, 1924.

Spiders from the Lake Abitibi Region. Univ. Toronto Studies, Biol. Ser. No. 32, 45-46, 1928.

Spiders of Nantucket. 4 pp. sep. publ., 1930.

Spiders of Nantucket. Nantucket Maria Mitchell Assoc., III., No. 2, 161-172. 1930.

\section{BIOLOGICAL NOTES ON CUBAN WASPS AND THEIR PARASITES}

\section{BY RICHARD DOW}

The material for the following notes was collected in Cuba during August and September, 1930. Through a scholarship from the Atkins Foundation, I was enabled to spend nearly five weeks at the Harvard Biological Laboratory near Cienfuegos, Santa Clara. The laboratory is located on the Atkins sugar estate, Central Soledad, and the situation is ideal for this sort of work.

I wish to thank the following people who have assisted me by determining material: Professor Nathan Banks, Mr. H. S. Barber, Dr. A. G. Böving, Miss E. B. Bryant, Mr. R. A. Cushman, Mr. Carl Heinrich, and Mr. J. A. G. Rehn. I am also indebted to Mr. S. C. Bruner of Santiago de las Vegas, Cuba, for permission to publish his observation on Chlorion cubensis, and Professor Joseph Bequaert, who has read my manuscript and identified all of the Vespidæ. Although the synonymy of these wasps is more or less tangled, I am using the names which will soon appear in a work on the West Indian Vespidæ by Dr. Bequaert and Dr. George Salt.

\section{Chlorion (Ammobia) dubitatum (Cress.)}

I found several nests of this species in a shallow clay pit near Belmonte, Central Soledad. They consisted of a 

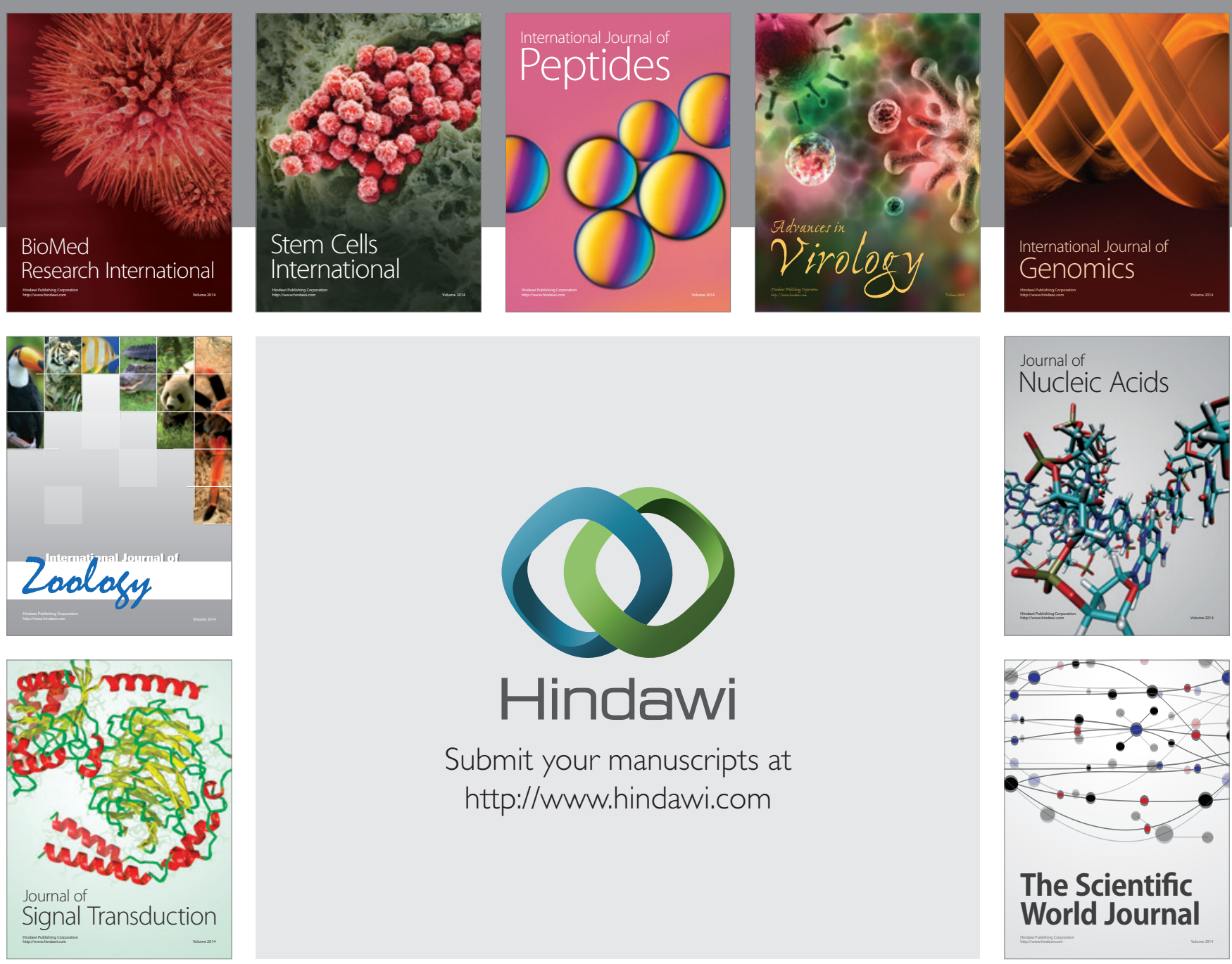

Submit your manuscripts at

http://www.hindawi.com
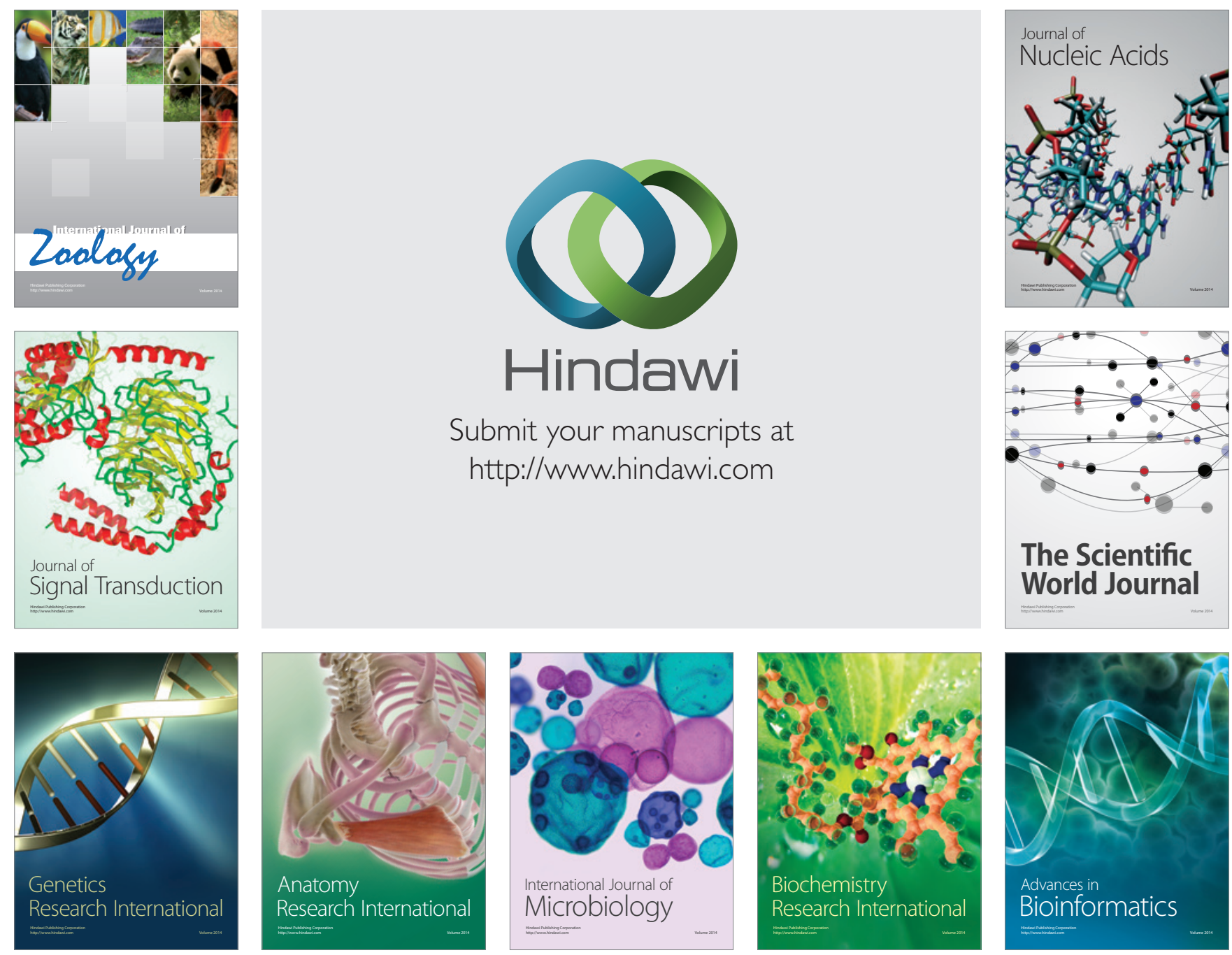

The Scientific World Journal
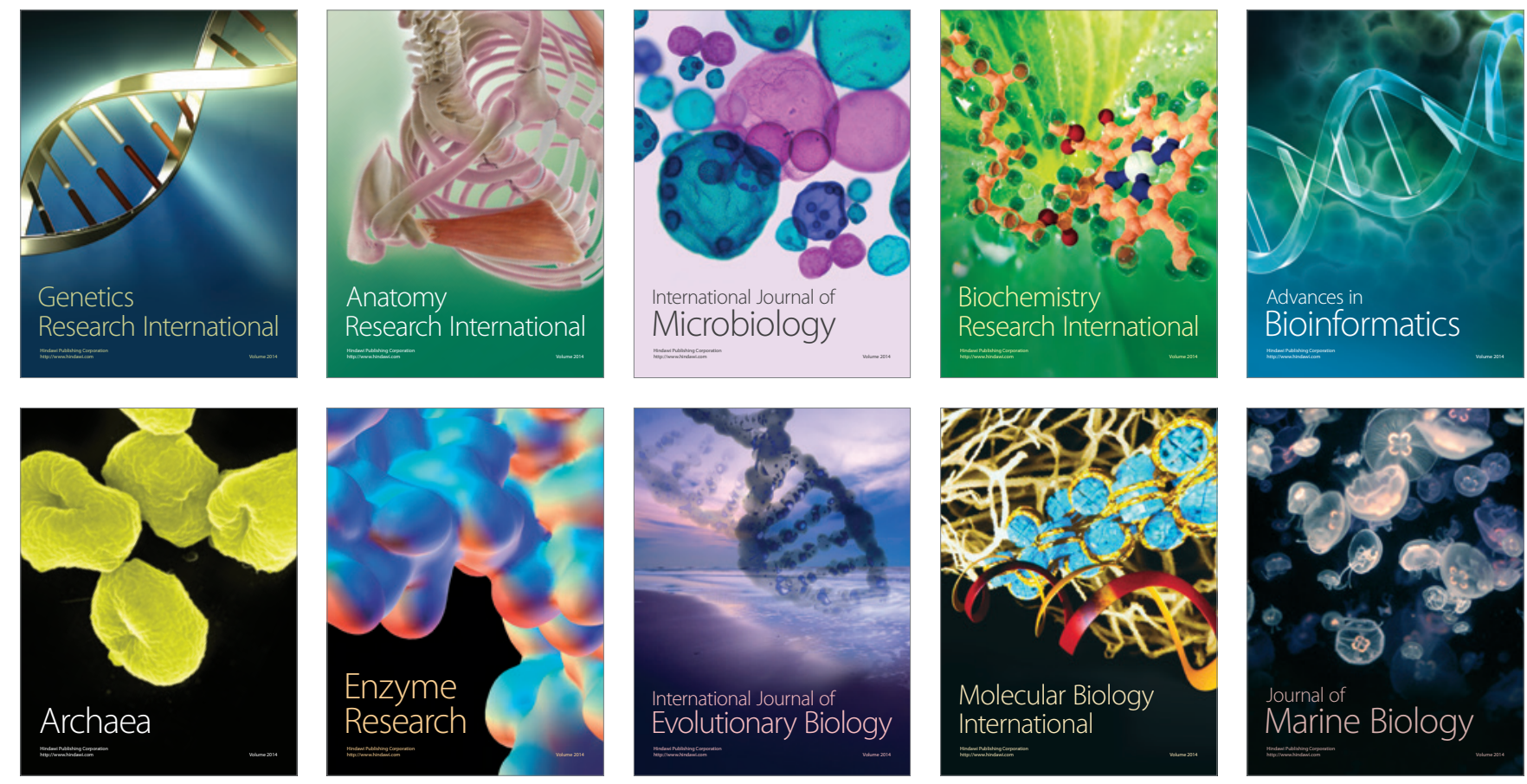